\title{
The role and measures of economic management in the development of state owned enterprises
}

\author{
Mengwei Shi ${ }^{1}$, Chunmei Song ${ }^{2}$, Fanhua Meng $^{3}$ \\ ${ }^{1}$ Department of Finance, Hebei Electric Power Vocation \&Technical Training Center \\ ${ }^{2}$ Department of Accounting, Shijiazhuang Vocational College of Finance \& Economics \\ ${ }^{3}$ Departmengt of Planning\&Operation, Hebei Electric Power Economic Research Institute \\ apx_shimw@163.com, bscm780929@163.com, cmengfanhua85@gmail.com
}

Keywords: Economic management; state-owned enterprise; function; measure

\begin{abstract}
With the development and progress of society and economy in our country, the importance of national prosperity and people's well-being of the state-owned enterprises are more and more outstanding, strengthen economic management of state-owned enterprises, improve economic management and control system is a long-term management goal of state-owned enterprises. In recent years, although the state-owned enterprises have made great achievements in economic management, but with the change of the national economic policy, its shortcomings are gradually exposed. In view of this, this article first introduces the role of economic management in the state-owned enterprises in the development, and then makes an objective analysis of the economic management of the status quo, finally puts forward the measures to strengthen economic management of state-owned enterprises, in order to economic management of state-owned enterprises to successfully carry out help.
\end{abstract}

\section{The role of economic management in the development of state-owned enterprises}

\subsection{Stability and coordination function}

The state-owned enterprises will follow the current market economy in the course of business rules, through stable and reasonable to carry out their own economic management work orderly reasonable allocation of productive forces of enterprises, in order to promote the optimal allocation of resources within the enterprise and between different regions of the economic activity coordination and dynamic optimization. The level of economic development in different regions often has gaps. Through the development of state-owned enterprises, the complementary advantages of different regions can be realized, thus narrowing the gap between regions.

\subsection{Innovation and breakthrough function}

Since the implementation of the policy of reform and opening to the outside world, great progress has been made in our economic construction. At present, China's different regions have formed a unique model of economic development and expanding these features of the mode of economic development not only has great role in promoting the development of regional economy, the national economy progress also play an irreplaceable role. It is precisely because of the existence of this regional economic model that the national economy has maintained the status of innovation and progress and maintained rapid development under the guidance of the national macro-control policy.

\subsection{Supplementary and auxiliary function}

At present, China's current national economy is dominated by industrial economy, and at the same time promoting the industrialization of state-owned enterprises in various regions continues to complement each other and complement each other. The important function of this industrial economic management mode is to promote the rational adjustment of regional industrial structure, 
and to promote the operation of state-owned enterprises in a healthy way while constantly improving their own management system. In addition, the industrial management mode between state-owned enterprises can also more fully guide the economic management of enterprises, and further consolidate the economic dominant position of state-owned enterprises.

\section{Problems in enterprise economic management}

\subsection{The enterprise financial management mechanism is not perfect}

In the development of modern enterprises, the purpose of enterprise management is to gain greater benefits. In the company's current development and future project management process, the enterprise financial management is of vital importance. Effective and scientific enterprise financial management can guarantee the stable operation and long-term development of the enterprise. However, in some enterprises in Xinjiang, the mechanism of financial management is not perfect, and their functions have not been brought into full play. In the enterprises in Xinjiang region, many operators of enterprises failed to realize this. In the actual operation and development, only focus on the development and marketing of goods management, financial management is too loose. For example, in the operation of enterprises, the use of funds for internal institutions is irrational, and there are many unreasonable funds expenditure projects. But for this kind of situation, the enterprise operator has not treated correctly. This increases the cost of capital to a certain extent. In addition, in the management of funds and accounts, the financial staff of enterprises use their functions and powers to distort the data information of enterprise accounts. These fully reflect the financial management mechanism of these enterprises is not perfect.

\subsection{The organization of enterprise's economic management is backward}

The enterprise's economic management organization mode fundamentally determines the management of enterprise development and progress. At present, many enterprises of the economic management organization way is too single, when the enterprise organization and management, but for a number of elements of products, industrial chain, organization scale, market development, analysis and synthesis, thus affecting the enterprise's economic management; enterprise management system at the same time not less cross each other, between different managers too much responsibility phenomenon is too serious, which is not conducive to establishing an effective corporate order; in addition, a lot of enterprise management work efficiency is low, many employees can not fully adapt to the management system and the organizational structure of the corresponding pipe, which reduces the effect of the development of enterprises in essence, is not conducive to enhance the core competitiveness of enterprises.

\subsection{The effect of enterprise human resource management is low}

As an important part of enterprise economic management, human resource management fundamentally determines the enterprise's economic development and comprehensive strength. At present, many enterprises do not pay attention to the effective management to the human resources, but for the enterprise human resources training and education, so as to reduce the overall strength and overall quality of human resources in essence, is not conducive to enhance their level of work, is not conducive to enterprise development and progress. Only by giving full attention to human resource management, establishing effective human resources management order, and constantly building a scientific incentive mechanism, can we fundamentally improve the effectiveness of enterprise economic management.

\section{Measures for strengthening economic management of state owned enterprises}

\subsection{Sound enterprise financial mechanism}

The management of enterprise finance plays an important role in enterprise management and development. Enterprises in Xinjiang should improve their own financial management system 
according to the existing laws and regulations. In the process of improving the financial mechanism of enterprises, we must first clear the functions of all departments and staff in modern enterprises, train the comprehensive ability and professional ethics of financial accountants, and regulate their financial activities. And then realize the standardization and openness of enterprise financial activities. Accountants who have illegal activities should be severely punished. For employees with excellent working conditions, they should be commended. In addition, we should establish an effective regulatory system and make full use of the role of internal control and internal audit in order to ensure the accuracy and reliability of enterprise financial accounts. And then make long-term development strategy for enterprises, improve reliable data, and ensure the steady development of enterprises.

\subsection{Optimize and refine the organizational structure of an enterprise}

Constantly optimizing and refining the organizational structure of an enterprise is of great significance for the realization of effective enterprise economic management. For the development of enterprises, it is necessary to constantly integrate enterprise resources, ensure the preciseness of enterprise organizational structure, and reduce the overlap of management content. Through the construction of enterprise organization tree to the enterprise effective management, and constantly improve the scientificity, effectiveness and organizational structure of the management organization of the discipline, in order to more clearly define the organizational structure of enterprises, improve the efficiency of enterprise development. At the same time, to eliminate the simplistic organizational structure of enterprise management, we should not blindly carry out the management of enterprise organizations in a straight line, but we must realize it by means of a variety of management methods.

\subsection{Innovating the reform and realizing effective human resource management}

Innovating the reform and realizing effective human resource management. Human resource is the center link of the business activities, should be effectively the enterprise human resources management mode innovation according to the specific situation of enterprises, effective management and evaluation of enterprise human resources, and train them to improve their service quality and management level; at the same time, but also to establish an effective incentive mechanism and evaluation the mechanism, improve the enthusiasm of the staff, constantly promote and optimize enterprise human resources, and create conditions for the economic development of the enterprise.

\subsection{Improve management quality}

The managers of the enterprise policy and have a decisive impact on business management, enterprise management of economic management and the importance of enforcement is the decisive factor of economic management practice smoothly and effective. Therefore, state-owned enterprises to improve the level of economic management, first make the enterprise managers to establish the correct management idea, improve the management level of the enterprise, to fully understand the importance and necessity of enterprise management work, and improve their own quality and management awareness, and strengthen legal consciousness.

\subsection{Middle-level cadres compete for posts, and improve the incentive mechanism for ordinary staff}

The characteristics of competition is fair and open competition, everyone can reflect in the selection criteria, procedures, open. It helps to arouse the enthusiasm, make everybody very serious attitude towards work, to improve work efficiency, improve work efficiency can improve the efficiency to a certain extent, but also the survival of the fittest. The competition is to broaden the channels of selection and appointment of personnel, as long as the qualified employees, you can sign up to participate in the competition, the opportunity to get promoted, and Voluntary Officers, have both ability and political integrity support of the masses of cadres talent shows itself has created favorable conditions. In addition, competition for posts is also conducive to strengthening 
the backbone of personnel selection and appointment of impartiality and scientific, consistent with the requirements of the post, comprehensive evaluation of people, the principle of employing director. It is beneficial to form a good atmosphere for people's job, unity and harmony, and adapts people's abilities, interests, hobbies and ideals to their positions so as to maximize their role.

\section{Conclusion}

To realize the necessary enterprise economic management is of great significance for the construction of enterprise order and the promotion of enterprise competitiveness, and relates to the survival and development of an enterprise. At present, many enterprises in the economic management has many problems, such as the way of enterprise management extensive economic backwardness, the enterprise human resources management efficiency is low, the organization for economic management is relatively backward, serious impact on the survival and development of enterprises. In this case, we must make clear economic goals, perfect enterprise management system and system construction, optimization and refinement of the organization structure, the innovation of human resource management mode, so as to continuously improve the effectiveness of enterprise management, deepen enterprise management reform.

\section{References}

[1] Wang Lingyan, Zhang Gang. Discussion on effective management and control methods of capital in state-owned enterprises [J]. Technology and economy age, 2011 (09): 44-46.

[2] Li Huanran. Discussion and Analysis on the management mode of state-owned enterprises in the new period [J]. Science Chinese, 2014 (23)

[3] Sun Jin. Economic management measures of state-owned enterprises under the new situation [J]. Chinese and foreign entrepreneurs, 2015 (1)

[4] Zhang min, Yuan jianpu. Discussion on improving the international competitiveness of enterprise management in China [J]. Management modernization, 2016 (1)

[5] Peng Lihong. International competitiveness of Chinese enterprises and analysis, [J]. Management world, 2015 (1)

[6] Wang Fujun. The source of International Competitiveness: Potter's interpretation, [J]., Nanjing Social Sciences, 1999 (11) 